Vol 47 No. 1 March 2014

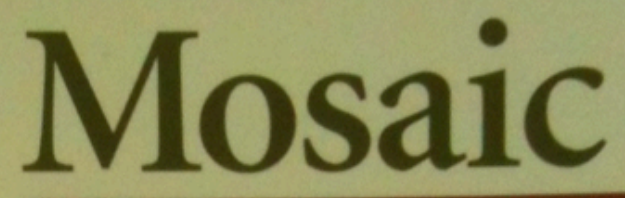

a journal for the interdisciplinary study of literature

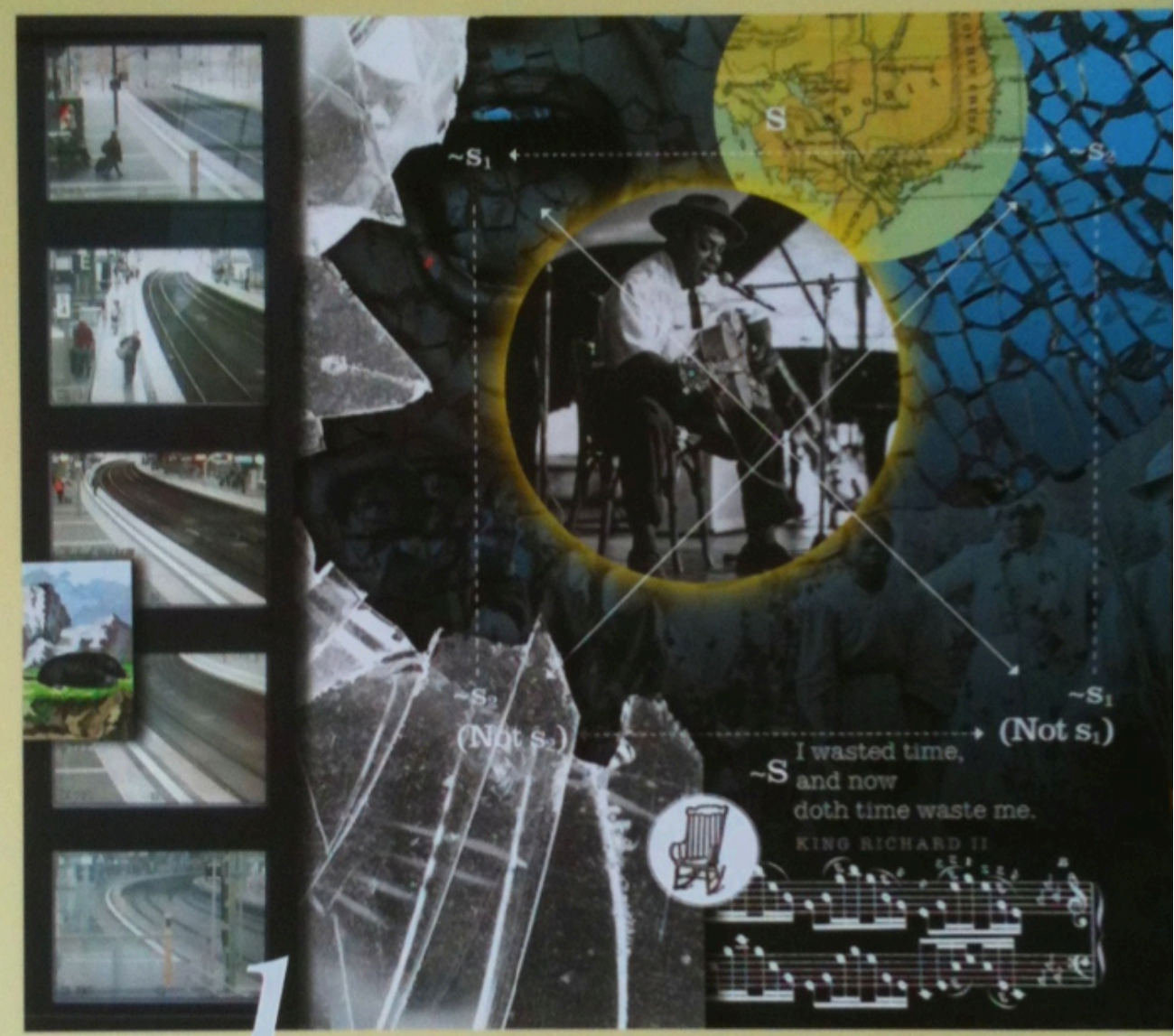

featuring:

NICHOLAS ROYLE 
Nathaniel Hawthorne's stories "The Rejected Blessing" and "Rappaccini's Daughter" dramatize ideological competition among doctors and clergymen from Renaissance Italy to colonial Boston over care of the body. In the context of Hawthorne's life, these stories show his foresighted theorizing of medical hegemony and its dangers to public and individual health.

\section{Nathaniel Hawthorne's Warring Doctors and Meddling Ministers}

ANTHONY CERULLI SARAH L. BERRY

$n$ the eighteen-thirties and eighteen-forties, Nathaniel Hawthorne (1804-64) was a young writer trying to make a living by submitting sketches, tales, and short stories to periodicals and gift books. Having declined his mother's suggestion to pursue a career in medicine, at Bowdoin (1821-25) Hawthorne studied classics and philology. He went on to position himself as a social critic aloof from all of the professions and as a keen observer of his contemporaries' foibles and obsessions. Hawthorne's life coincided with a period of intense struggle in American medicine between academic, or "regular," medicine and a multitude of alternative healing systems, collectively referred to as "irregular" practices, such as Thomsonianism, homeopathy, eclecticism, and water cure. As regulars and irregulars vied for the public's trust and business, each touted the virtues of their own cures. College-educated physicians, following Benjamin Rush's heroic revolution in therapeutics, turned away from complex medicines with dozens of ingredients and began using heavy doses of opium, mercury, antimony, quinine, and arsenic, along with blood-letting by leech or 
lancet for nearly every illness (Haller 67). At the same time, alternative healing systems sprang up everywhere between the Jacksonian period (eighteen-twenties and eighteen-thirties) and the Civil War in response to the pain and worsening of illness that regular medicine offered. Alternative systems were more affordable than regular medicine, with milder side effects on patients; and, as Thomsonianism encouraged, many of them allowed patients to treat themselves.

For young Hawthorne, the conflict between regulars and irregulars and its implications for power over one's personal health and happiness was more interesting than subscribing to a particular healing system. He ultimately rejected a medical career because, he wrote, he did not want "to live by the diseases and infirmities of my fellow creatures. And it would weigh very heavily on my conscience if, in the course of my practice, I should chance to send any unlucky patient 'ad inferum,' which being interpreted is 'to the realms below'" (qtd. in Mellow 25). With this sardonic view of the profession as parasitic on human frailty and his fear of doctors' ability to kill their "fellow creatures," Hawthorne accordingly created characters who were singleminded and deadly, such as Aylmer in "The Birthmark," Drs. Rappaccini and Baglioni in "Rappaccini's Daughter," and Roger Chillingworth in The Scarlet Letter.

Early in his writing career, Hawthorne scorned the specious nature of claims made by reformers of human health and happiness. In 1835 he noted the following premise for future tales: "A sketch to be given of a modern reformer-a type of the extreme doctrines on the subject of slaves, cold water, and other such topics. He goes about the streets haranguing most eloquently, and is on the point of making many converts, when his labors are suddenly interrupted by the appearance of the keeper of a mad-house, whence he has escaped. Much may be made of this idea" (qtd. in Mancall 7). Yoking abolitionists and water-cure practitioners as “extreme," Hawthorne's main interest here is that the danger of the vocal and public reformer is his illusive power to win the belief of his audience. Hawthorne would return to the figure of the "modern reformer" again and again in his fiction throughout the eighteen-forties. In 1841, he "made much of this idea" in "The Rejected Blessing," a historical tale in The Whole History of Grandfather's Chair, or True Stories from New England History, 1620-1808, chronicling Boston minister Cotton Mather's early activism for inoculation against smallpox. A few years later, he elaborated on "extreme" reform and its backlash in "Rappaccini's Daughter." Hawthorne's cultural observations of hotly contested medical systems competing for public trust as well as his personal experiences of illness and treatment shed light on his fictional illustrations of medical harm and ideological competition.

In this essay, we argue that Hawthorne's stories theorize medicine as a cultural institution that has within it multiple competing modes of healing. This professional 
warfare within the medical institution, Hawthorne's short stories suggest, produces claims that confound and obscure the best interest of patients in favour of hegemonizing medical authority. We examine "The Rejected Blessing" and "Rappaccini's Daughter" in their historical contexts and argue that each story dramatizes a perennial problem in institutional healthcare. Identifying the portrayal in these stories of the pitfalls and arbitrary nature of theoretical unilateralism in institutions of healing, we suggest that Hawthorne offers a subtle yet lucid account of hegemony and the practices of hegemons in medical history. His careful reading and representation of medical history express Gramscian views of hegemony, wherein cultural institutions such as medical schools, physicians' organizations, and religious groups aspire for legitimation in the public domain through ideological tactics (Selections 54). Hawthorne dramatizes these tactics in forms like the unfair manipulation of clergymen and students by medical professionals in an effort to defame competition and to repackage competitors' ideas as one's own.

U awthorne's fictional depictions of medical history present characters who seek to legitimate their scientific authority through discursive and occasionally coercive tactics. His storytelling suggests that when cultural authorities vie for legitimation they frequently employ ideological tactics, seeking to colour the ideas, dispositions, and values of the public by, in Paul Ricoeur's words, adding "a certain surplus-value to our belief in order that our belief may meet the requirements of the authority's claims" (Lectures 183). Because "there is always more in the claim which comes from the authority than in the belief that is returned to it," according to Ricoeur, there is a perennial "excess of the demand for legitimation in relation to the offer of belief." In this imbalance "ideology asserts itself as the transmitter of surplus value and, at the same time, as the justificatory system of domination" (Text 252). Hawthorne portrays ideological competition - the vying for legitimation and authority_among healing practitioners and institutions as an impediment to achieving optimal care of the body. By exposing the professional and self-interested contestation for bodily care, Hawthorne's stories provide insight into the social and political formation of medical authority in the past.

One way Hawthorne pursued his idea of "extreme doctrines" was in a sketch about the eighteenth-century smallpox vaccination controversy in New England, led by Puritan minister Cotton Mather (1663-1728). After college, Hawthorne read prodigiously. He was particularly fascinated with Magnalia Christi Americana, which he described as a "strange, pedantic history, in which true events and real personages move before the reader with the dreamy aspects which they wore in Cotton Mather's 
singular mind" (qtd. in Mellow 40). ${ }^{1}$ Hawthorne was most interested in the medical profession's rejection of new treatments, especially those promoted by a clergyman. This rejection echoed the blasts of physicians in the eighteen-forties against supposedly unqualified "quack" reformers. In Hawthorne's own backyard, Harvard physician Oliver Wendell Holmes denounced irregulars in a venomous 1842 speech later published as "Homeopathy and Its Kindred Delusions" (Browner 94). John S. Haller notes that regulars in this era "had closed their minds to ideas and facts that fell outside their neat intellectual worlds" (99). The irony that Hawthorne foregrounds in "The Rejected Blessing" is that Mather, reviled by the public and the medical establishment alike, turned out to have the medical solution to smallpox epidemics.

Two people in Boston's history, Cotton Mather and William Douglass (c. 16911752), epitomized for Hawthorne the collision of medical ideologies. Whereas Mather advocated inoculation against smallpox, Douglass, a Scottish-born academic allopath, championed the use of regular medical practices. Hawthorne's attention to this conflict in "The Rejected Blessing" suggests his identification of the colonial roots of hegemony within American medicine and, for counter-discourses, the difficulty in finding a sociopolitical platform for one's ideas. Although Hawthorne does not name him, historians identify William Douglass as the key figure responsible for publicly rejecting Mather's attempts to protect Boston from the smallpox disease. In "The Rejected Blessing" Hawthorne focuses on Mather, who appears as a maverick figure challenging established medical tradition. That Mather is also a Christian clergyman adds depth to Hawthorne's commentary on ideological competition by demonstrating the discursive links across cultural institutions on the issues of health and care of the body.

"The Rejected Blessing" retells the "terrible calamity" of the 1721 smallpox epidemic, the seventh that had ravaged New England since 1630 (96). The chronological sequence of history tales in Grandfather's Chair creates a teleological structure for Mather's foresight and eventual medical martyrdom. "The Rejected Blessing" presents a clear case of scientific efficacy that is at first spurned both by medical authorities and by the public, then observed to save lives. Furthermore, Hawthorne's narrator, Grandfather, strongly asserts Mather's wisdom, while he also chides the "forefathers" for not recognizing Mather's humanitarian contribution during his lifetime. His final judgment of Mather's righteousness is the (rather reductive) assertion that because of his work, the danger of smallpox is now safely behind the people of the new American republic (103). This story in particular begins to address key aspects of ideological manipulation that Hawthorne would later develop and complicate in "Rappaccini's Daughter." In both stories, Hawthorne emphasizes the war of words and violent backlash against practitioners of alternative therapies. 
As a new outbreak of smallpox unfolds in colonial Boston, in "The Rejected Blessing," Cotton Mather, the character, is consumed with apprehension as he stumbles across a Royal Society publication on inoculation. Believing this discovery among his books is providential, he begins his famous campaign among the city's doctors to implement the practice. Here Hawthorne applies the formal title of "Doctor" to Mather, which stresses external validation and legitimation of Mather's cultural authority (96) and, we suggest, signals the hegemony of allopathy by Hawthorne's time of writing. That is, after one hundred and twenty years, Mather's advocacy for inoculation had been thoroughly absorbed by the dominant medical institution, represented in Mather's time by William Douglass, who staunchly opposed the practice but eventually came to employ it himself. As Maxine van de Wetering observes, Douglass and the Boston doctors simultaneously co-opted and renounced Mather's and Zabdiel Boylston's ideas about inoculation. But as representatives of the prevailing medical discourse of the day, they were able to transmit "medical statistics measuring recovery rates [that] validated the claims of Boylston and Mather" and to repackage that data in view of inoculation practices they had integrated in the clinical sphere of academic medicine. And yet, van de Wetering notes, "the old rancor continued" (50), for despite his apparent acceptance and practice of inoculation, Douglass persisted in critiquing Mather and Boylston on the very issue. Hawthorne's use of "Doctor" with respect to Mather reveals the author's sensitivity to the hegemony of allopathy in his day. It might also be seen as Hawthorne's subtle critique of the emptiness of professional titles popularly perceived as weighty in the bid for cultural authority.

Hawthorne's representation of Mather, however, aligns historically with Mather's medical training and knowledge. Mather showed a keen interest in medicine from a young age. He served as an amanuensis for the famous physician William Avery, who worked tirelessly throughout his career on smallpox and its prevention (Silverman 338). Mather went on to study medicine at Harvard College, and although he never officially became a doctor, he studied medicine throughout his adult life. By the end of his life, his medical studies and writings earned him the distinction of being the only American minister elected to the Royal Society (Totaro 3). During the 1702-03 smallpox epidemic Mather had tried unsuccessfully to persuade Boston physicians to consider more moderate methods of controlling the disease, methods like the "cold regimen" introduced by the seventeenth-century British physician Thomas Sydenham, in which patients were kept in cool, fresh air and plied with cold beverages. At the time, many physicians were treating smallpox with "heat therapies," including sweating, bleeding, and purging regimens. Mather's famous essay 
"Curiosities of the Smallpox," which he submitted to the Royal Society in 1716, entreats Dr. John Woodward to encourage physicians to begin practicing inoculation in England (Silverman 338). While we know that Mather had studied and published on inoculation prior to the 1721 outbreak of smallpox in New England, Hawthorne chooses to suppress this information and instead emphasize Mather's "great affliction for the sake of the whole province" and for his children. In Hawthorne's version, then, Mather's compassion-itself a source of suffering, like illness-becomes the cause of his "discovering" a publication detailing the practice of inoculation ("Rejected" 98).

While Hawthorne incorporates language from Mather's diary entry of 26 May 1721 ("I will procure a Consult of our Physicians, and lay the matter before them"), ${ }^{2}$ his narrator balances Mather's power between knowledge and piety: "Either the wisdom of so learned a minister would find some remedy for the danger, or else [...] his prayers would secure protection from on high" ("Rejected" 99). But Grandfather's opinion does not match that of Mather's contemporaries. For when Mather began canvassing physicians in Boston to practice inoculation, he met with resistance and ridicule. Douglass, who earned his degree in the British medical system, where title and hierarchy were highly valued, was shocked by the lack of professional structure in Boston's medical community. Thus when the non-credentialed minister began to speak out in medical matters, especially about something as serious as smallpox, Douglass could not withhold his objections and led the medical establishment to revile Mather publicly.

Hawthorne's illustration of professional warfare changes between "The Rejected Blessing" and "Rappaccini's Daughter." In the earlier story, he unambiguously blames academic medical men by turning to sarcasm: "They were a very wise fraternity; and their huge wigs, and black dresses, and solemn visages made their wisdom appear even profounder than it was [...] But the grave and sagacious personages would scarcely listen to him." Calling attention to the social and professional status of doctors (compared with the minister) as covering over a lack of both scientific innovation and humane motivation, they resemble Professor Baglioni in "Rappaccini's Daughter," as we will see. One reason for the doctors' rejection of Mather's proposal closely echoes Baglioni's allegiance to academic orthodoxy: "No such thing as inoculation was mentioned by Galen or Hippocrates; and it was impossible that modern physicians should be wiser than those old sages" (99). The academy, once again in Hawthorne's long view of history, retains its traditional authority by blocking new methods in effective disease prevention. "The Rejected Blessing" ultimately delivers this judgment more bluntly than does "Rappaccini's Daughter," which also impugns the innovator, Rappaccini, by withholding the "proof" of efficacy for each side. 
Hawthorne's Mather, positioning himself above all considerations as obedient to God, viewed inoculation as a means to save both bodies and souls. Hawthorne again invokes the local doctors' response to Mather's innovation as an episode of professional warfare. Accusing him of clerical meddling, a doctor of regular medicine "requested, in the name of the whole medical fraternity, that Cotton Mather would confine his attention to peoples' souls, and leave the physicians to take care of their bodies" ("Rejected" 99). The opposing physicians "arose in great fury and began a war of words, written, printed, and spoken, against Cotton Mather and Doctor Boylston," the sole physician who agreed to implement Mather's inoculation plan and who had published his own Account of What Is Said About Inoculation. Boylston stood opposed to the entire medical community in Boston, not to mention most of the citizenry, and Mather tried fervently to show his support for Boylston by writing in his defense in pamphlets and the local papers. Yet Hawthorne underscores not Mather's side of the writing campaign, but rather the mud-slinging aims of those eager to retain their authority in the face of outsider or irregular innovation: "To hear them talk, you would have supposed that these two harmless and benevolent men had plotted the ruin of the country" (100). For his part, Cotton Mather frequently responded to attacks with a theological defense rooted in Christian compassion and a concern to prevent human suffering. As a man of the cloth, he was concerned for and empathic toward those who suffered from smallpox as well as for those who might suffer from it in the future.

The inoculation debate in Boston played out not only in public black-letter tracts among scientists, but also through rumour and hearsay among the public, which stirred up hostility: people tended to believe that Mather and Boylston aimed to spread "the gout, rheumatism, sick-headache, asthma, and all other diseases [. . .] through the whole community" ("Rejected" 100). Hawthorne's narrator echoes Mather's own description in his diary (Diary II 632) of a hostile public, so violent that "in the winter of 1721 he began to talk of his 'approaching martyrdom' and feared that he would be assassinated" (Letters 339). Mather's suspicions were confirmed shortly after inoculating his nephew, Thomas Walter, when someone threw a grenade into his bedroom on 14 November 1721 (he was unharmed). A note from the grenade-thrower read, “Cotton Mather, You Dog, Dam you: I'l inoculate you with this, with a Pox to you [sic]" (Diary II 658). This reveals the common conflation of the disease and its preventative cure among the opposition. To those opposed, the pox and the inoculation are the same "poison."

In the story, Mather's motivation is rooted in his compassion for his family and congregation, and he promotes a medical practice that ultimately saves lives. "The Rejected Blessing" structures the epidemic and Mather's role in introducing inoculation 
to Boston teleologically. Hawthorne's portrayal of Mather overall is quite laudatory, for he sees Mather as an important trailblazer and medical reformer. The very title, "The Rejected Blessing," and the story's concluding remarks bear this out:

\begin{abstract}
Men who attempt to do the world more good than the world is able entirely to comprehend are almost invariably held in bad odor. But yet, if the wise and good man can wait awhile, either the present generation or posterity will do him justice. So it proved in the case which we have been speaking of. In after years, when inoculation was universally practised, and thousands were saved from death by it, the people remembered old Cotton Mather, then sleeping in his grave. They acknowledged that the very thing for which they had so reviled and persecuted him was the best and wisest thing he ever did. (100)
\end{abstract}

In this first sketch of medical competition, the orthodox medical establishment represents the "type of extreme doctrines" that so intrigued Hawthorne and lay at the heart of his social criticism. Hawthorne plays up the point that harm comes from medical hegemony in his portrayal of Cotton Mather by ascribing compassionate reasons to the fictive minster's medical innovations, while suppressing the real-life minister's participation in the production of medical knowledge.

0 nly a few years after the historical lessons of Mather's medical solution to smallpox had appeared in Grandfather's Chair, characters embodying the "extreme types" Hawthorne observed in eighteen-forties Massachusetts resurfaced in the more complex and clearly allegorical story "Rappaccini's Daughter," published in the December 1844 issue of Democratic Review. This story dramatizes in greater detail than "The Rejected Blessing" the professional warfare between a regular, academic physician and an irregular medical experimenter. Unlike "The Rejected Blessing," this story foregrounds ambiguity in a contest between two equally extreme characters by suppressing judgment about which man's method is therapeutically sound. What is more, "Rappaccini's Daughter" exemplifies the power of medical men to harm and even kill—a "type" that also fits Hawthorne's character Aylmer in "The Birth-Mark," preceding "Rappaccini's Daughter" by one year, and that would characterize Roger Chillingworth when Hawthorne wrote The Scarlet Letter in 1850. To explain Hawthorne's more elaborate allegorical critique of competing medical systems in "Rappaccini" compared with "The Rejected Blessing," we turn to the dense cluster of medical events that the author experienced in the intervening years.

After Grandfather's Chair came out, Hawthorne tried to support himself and his wife, Sophia Peabody, whom he married in 1842, by publishing short fiction in the booming magazine market. His twenty tales and sketches published in 1843 and 1844 
"were heavily burdened with allegorical intentions and an underscored morality" (Mellow 230, 233). Tales like "Rappaccini's Daughter" were "social critiques, catalogues of human types and vanities. [...] The same characters appear and reappear in his allegories: the fanatic and the reformer, the theorist, the disgruntled author, the failed politician, the militant feminist" (234). Hawthorne's friends Bronson Alcott, Henry Thoreau, Margaret Fuller, and Ralph Waldo Emerson were leading modern debates about social perfectionism. Always hovering around their circle, Hawthorne refused allegiance to any doctrine. In these years, fanatics and reformers came under his explicit critical treatment in fiction for the first time. For example, "Earth's Holocaust" displays Hawthorne's "first innuendo about the tyranny of reform" (235); "The New Adam and Eve" is a pessimistic view that post-apocalyptic humankind would repeat the errors of the past; and "The Celestial Rail-Road" offers a sardonic parody of abolition and John Bunyan's allegory Pilgrim's Progress. "Rappaccini's Daughter," published at the end of this period, in our view presents Hawthorne's most complex and withering criticism of institutional competition in the medical realm.

While Hawthorne's characters in "Rappaccini's Daughter" are composites, each is clearly inspired by people in his own life. Sophia Peabody's history of invalidism since infancy and her family's intense involvement with both regular and irregular medicine provided Hawthorne with plenty of ideas for "Rappaccini's Daughter." A skeptic of medicine since his youth, Hawthorne now had first-hand experience of living with an invalid and, as a new husband, a personal investment in his family's health.

Sophia's life reads as a virtual encyclopedia of medical poisons and the vulnerability of women under paternal care. Her father, Nathaniel Peabody, a doctor and dentist, dosed her heavily with "narcotics" (Wineapple 116) during teething, and for the rest of her life she suffered illness and headaches. Throughout childhood and adolescence, Sophia visited a phalanx of Boston doctors for her severe headaches; she lived in partial seclusion, frequently incapacitated, and had taken the heroic doses of mercury, arsenic, and opium typical of her day (Mellow 135). Dr. Walter Channing, an influential member of the Concord Transcendentalist circle that Hawthorne included as friends, campaigned to restrict medicine to professional doctors. His 1820 pamphlet against midwifery, sharply denouncing women's traditional birthing work, is one of the earliest efforts to appropriate childbearing to professional medicine. For Sophia, Channing prescribed strong treatments of both mineral and plant drugs, including hyoscine, a depressant extracted from plants of the nightshade family, deadly in highenough doses. After a particularly stringent course of purging via arsenic prescribed by Channing, the whole Peabody family switched to homeopathy "to purge themselves of poison" (Wineapple 116). Sophia's sister Elizabeth later "converted" to homeopathy and sold homeopathic medicines in her book shop. 
In her teens, Sophia was sent to Cuba to gain strength. Unlike her worsening of illness during Channing's drug regimens, she flourished in the tropical climate, becoming happy and healthy, riding horses and socializing. The exotic flora and fauna stimulated her. A night-blooming cereus, a large cactus flower "that filled the air with a heady fragrance," particularly captured her attention. Alongside a sketch in her notebook, she enthused, "nothing more could be asked for in a flower-I wished for no more excepting that it were immortal_deathless" (qtd. in Mellow 136, emph. Peabody's). Hawthorne carefully read her notebooks before they married (144).

After her marriage, Sophia's invalidism and dependence on doctors resumed. Around the time Hawthorne was writing "Rappaccini's Daughter," Sophia suffered a miscarriage (February 1843), shortly thereafter becoming pregnant (July 1843) and having a healthy birth. But her headaches returned soon after the child was born and, in April 1844, she went back to Boston for three weeks of treatment with a Dr. Wesselhoeft, leaving her husband behind in Concord. The Hawthorne family narrative that Dr. Peabody had permanently poisoned his infant daughter continued when Julian wrote in his biography of his parents that Sophia was "incontinently dosed with drugs, from the harmful effects of which she never recovered" (qtd. in Mellow 133). In "Rappaccini's Daughter," Hawthorne would pull together diverse strands from his wife's history and the professional warfare that implicitly harmed her as it raged around their quiet Concord home in the eighteen-forties.

"Rappaccini's Daughter" is a story informed by Sophia and Nathaniel Hawthorne's fears: Beatrice is fatally poisoned by her father, a reformer, and his rival, an orthodox physician. Each practitioner's medicines combine to deliver the deathblow. Yet, unlike the clear correctness of the character Cotton Mather, Hawthorne does not identify which doctor is superior by introducing a fourth character, the naïve student Giovanni, who arrives in Padua, a centre of medical innovation in the fifteentwenties, to study medicine with Professor Pietro Baglioni. Before long, he finds himself embroiled in a battle for scientific authority between Baglioni and his rival, the experimenter Doctor Giacomo Rappaccini. The doctors contend for Giovanni's allegiance in the hope that Giovanni will take up the particular scientific pedigree each doctor endorses. In so doing, each doctor reveals his opposition to the other's medical practices and theories. The story ends with a showdown between the doctors, in which Baglioni's antidote to Rappaccini's poison kills Rappaccini's daughter, Beatrice. ${ }^{3}$ Hawthorne ends the story with profound equivocality, for the gripping dénouement does not reveal which medical practice is ultimately more effective. Hawthorne instead directs the reader's attention to the harmfulness of the men's "warfare" itself. 
Among Hawthorne's literary treatments of scientific power, only "Rappaccini's Daughter" pits two medical men against each other. To date, scholars have established Hawthorne's historical accuracy in setting "Rappaccini's Daughter" in Padua during the Italian medical Renaissance. Yet no one has focused on the competition between academic and experimental medical science exemplified by Baglioni and Rappaccini. ${ }^{4}$ Hawthorne presents Professor Baglioni as a devotee of Galenic allopathy, while Rappaccini emerges as a medical reformer, a hybrid of Paracelsus (1493-1541) and the "cold water" healers and homeopaths of the eighteen-forties, whose therapies were so radical that they were regularly regarded as poisoners. Yet the ambiguous ending suggests that the veritable poison in this story lies less in the medicines themselves than in the nature of struggle for authority, which at all costs pits people against each other in a bid for the public's confidence.

While Baglioni and Rappaccini clearly represent two distinct medical systems, Giovanni's infatuation with Rappaccini's daughter, Beatrice, makes him an unreliable witness to both physicians. He is susceptible to Baglioni's slanderous campaign against Rappaccini while he can only conjecture about Rappaccini, who does not divulge his theories or practices to the young student. Giovanni and the reader learn together in the story, not about the integrity of Baglioni's allopathy or the efficacy of Rappaccini's potent herbals, but instead about the personal interests of each scientist. In the process, an altogether new view emerges: Giovanni's fickle beliefs about the potential healing and harming powers of each doctor reveal Hawthorne's larger commentary that ideological competition among medical men bears significant consequences, which inevitably play out among unwitting subjects, such as aspiring students and the young women who take medicines. Anticipating Ricoeur's recognition that ideology arises from "the open conflictual situation of modernity" (Lectures 261), Hawthorne's dramatizations of medical conflict illustrate legitimation as indivisibly tied to what Sheldon Pollock has called "ideology in the strong sense-that is, false consciousness, misrecognition, discourse of false necessity, and the like" (519). As analytic terms, ideology and legitimation operate within the orbit of hegemony as Gramsci conceived it, for both terms, indissolubly linked, involve discourses that reproduce domination by generating social consensus (Pre-Prison 261, 312). ${ }^{5}$ Baglioni's verbal posturing is calculated for precisely these ends, with the primary aim of maintaining his seat of authority by manipulating Giovanni into aligning with allopathic orthodoxy and rejecting the irregular counter-discourse of Rappaccini. As an impressionable young student, moreover, Giovanni stands in for the public amid the scientific jargon of professionals, which is so often unintelligible to the masses and, in particular, the next generation of medical scientists. 
To foreground Hawthorne's views on medical ideology, it is useful to trace each scientist through Giovanni's biased viewpoint. While Baglioni is mentioned first in the story, Rappaccini first appears to the young student (and the reader). From the moment of Rappaccini's introduction, neither the reader nor Giovanni gets an objective view of him. Lisabetta, Giovanni's housekeeper, informs him, based on hearsay ("It is said. . ."), that Rappaccini is an alchemical and botanical scientist who distils "plants into medicines that are as potent as a charm" (977). From the distance of his upper-story room, Giovanni observes Rappaccini merely as "a tall, emaciated, sallow, and sickly-looking man, dressed in a scholar's garb of black" (978). Giovanni particularly notices Rappaccini's “intentness of examination” of a brilliant, perfumed, flowering shrub like Sophia's night-blooming cereus. Rappaccini is remote and mystical, appearing to discern properties or causes beyond science. What puzzles Giovanni most is that "despite his intelligence, there was no approach to intimacy [with the shrub]" (978-79). Soon Giovanni sees Beatrice enter the garden, "beautiful as the day, and [mirroring the lush plant] with a bloom so deep and vivid that one shade more would have been too much"; in contrast with her father "she looked redundant with life, health, and energy" (979). Combining Sophia's observations of the luxuriant cereus with the beautifying effects of her nightshade medicine, hyoscine, which dilates the pupils and raises colour, Beatrice's superfluous vigour seems unnatural; combined with the effects of Lisabetta's gossip, these observations skew our judgment of Rappaccini and Beatrice, suggesting a surplus value of ideology.

After observing Rappaccini in his garden, Giovanni next sees him on the street at the same time as he runs into Baglioni. Rappaccini's behaviour is again suspicious: he "exchange[s] a cold and distant salutation with Baglioni" and mysteriously gazes at the student, causing Baglioni to exclaim that he believes Giovanni is a part of his rival's scientific experiments (988). Giovanni, confused by his feelings for Beatrice, is unable to discern Rappaccini's true intentions. After this encounter, Rappaccini effectively disappears; in each of Giovanni's subsequent visits to Beatrice in the garden, the doctor is absent. In the final scene, Beatrice swallows Baglioni's purported antidote. Not realizing that she has done this, Rappaccini enters the garden and reveals his scientific intentions: "My science, and the sympathy between thee [Beatrice] and him [Giovanni], have so wrought within his system, that he now stands apart from common men, as thou dost, daughter [...] from ordinary women" (1004). He admits that he has imbued her and, through her, Giovanni, with botanical substances so that they would not be "exposed to all evil, and capable of none" (1005). Keeping in mind that "evil" is a synonym for disease in this period, Rappaccini declares that his science on Beatrice, and the force of sympathy-making two people similar, as in the homeo- 
pathic law that like cures like-has done the work of imparting her condition to Giovanni. Beatrice, who perishes from the mixture of Baglioni's medicine with her father's, insists that his medical experiment has inflicted "miserable doom" and estrangement from society-an invalid's life like Sophia's. But never does Rappaccini call his botanical substances poisons.

In contrast to Rappaccini's mystical retirement from public life, Hawthorne gives Pietro Baglioni much more voice and action. He is introduced as a "friend" of Giovanni's father and through his credentials as a "professor of medicine in the University, [and] a physician of eminent repute" who practices "the divine art of [academic] medicine." To buttress his seeming benevolence, Hawthorne gives him a "genial" and "jovial” character (981). Suspecting nothing, Giovanni stumbles upon the conflict between the two doctors when he first asks Baglioni about Rappaccini, assuming that they are equals, both "men of science." It is Baglioni who, upon a violent reaction to hearing queries about his rival, initiates "professional warfare" (982-83). From this moment, Baglioni's judgments replace the gossip of Lisabetta and infiltrate Giovanni's — and the reader's - perception of Rappaccini with the weight of professorial authority. Suddenly Giovanni's beliefs, formed from his independent observations, are influenced by Baglioni.

Baglioni's competitiveness escalates when Giovanni becomes obsessed with Beatrice. First Baglioni warns Giovanni to stay away from the Rappaccinis with "grave objections to [Dr. Rappaccini's] professional character," including his caring "infinitely more for science than for mankind" (982). Baglioni consistently portrays Rappaccini as a mad scientist and deranged man rather than as a serious and benevolent physician. For example, Baglioni intends to rescue Beatrice from a dangerous science: "We may even succeed in bringing back this miserable child within the limits of ordinary nature from which her father's madness has estranged her" (998). As Giovanni observes Beatrice more, and struggles to determine whether she is indeed poisonous, he avoids Baglioni. When he meets Baglioni on the street as Rappaccini is passing by, the professor warns Giovanni that Rappaccini is secretly using the young student in his "experiments" with plant "poisons" (988). This chance encounter of the two medical men and the student in public emphasizes the war of words, while obscuring the men's professional motives.

After a long period of no contact between professor and student and far into Giovanni's courtship of Beatrice, Baglioni seeks out Giovanni to deliver an anecdote about Alexander the Great and the Poison Woman (996). But in Giovanni's apartment, detecting what he considers to be Rappaccini's poison, Baglioni becomes more heavy-handed. Baglioni prepares an "antidote" for Beatrice and convinces Giovanni to administer it to her. When Beatrice dies as a result, Baglioni is both triumphant and 
horrified, and the story ends when he rhetorically asks Rappaccini, "And is this the upshot of your experiment?” (1005, emph. Hawthorne's). By giving Baglioni the last word in the story, Hawthorne suggests that in the collision of ideological systems, the optimal result of competition - in this case, health-is often negated in the competitive heckling raised by those who aim to retain their cultural authority. Contrary to Baglioni's boisterous criticism of Rappaccini and his experiments, Rappaccini never voices his own methods. Nor does he declare opposition to Baglioni's allopathy. By the end of the story, the layers of obfuscation have led the reader to the same inconclusive point as that reached by Giovanni. Each doctor manipulates Giovanni in very different ways for his own professional ascendancy. Baglioni defeats Rappaccini by having Giovanni destroy his experiment. Rappaccini, on the other hand, conceals his scientific plans for Giovanni and Beatrice until the end of the story, where he implies that he has engineered Giovanni to carry, with Beatrice, the powerful botanical substance out into the world (1004). While Baglioni relies on slander and murder, Rappaccini combats his opponent from behind the scenes by attempting to marry Beatrice and Giovanni so that they will reproduce and thus extend his most elaborate experiment.

With the trope of poison, Hawthorne comments on the ways in which professional competition harms (i.e., poisons) the minds of an unsuspecting public. Poison in this story refers not only to several literal historical narratives-as with Alexander the Great's "Poison Woman" and the debate over homeopathic medicine as being poisonous from the late-eighteenth century on - but also to the operation of ideological competition, which Hawthorne illustrates through the indoctrination of Giovanni and, by extension, the casual observer in the public domain. When Giovanni shows poisonous traits by killing plants and insects, Hawthorne's poison trope raises the question as to which scientist, Rappaccini or Baglioni, has used poison on him. Baglioni believes Rappaccini is a poisoner. His concern for Giovanni is not altruistic, however, but competitive and ideologically driven in a fundamental, conflictual sense: "We will thwart Rappaccini yet!' thought he" (998). The use of the first-person plural "we" co-opts Giovanni into the fold of his practice and rhetoric by portraying Rappaccini as an obstacle to the continued reproduction of Baglioni's academic theories as the dominant medical discourse. Moreover, this alliance effectively deflates any momentum and organization of the lesser known, counter-medical movement of Rappaccini.

Baglioni's intentions precipitate the story's disastrous ending. Regardless of Rappaccini's science, Baglioni's "antidote" is fatal. This raises important questions: Is Beatrice's death by the "antidote" a reversal of antidote and poison? Or does Baglioni know that the antidote is lethal, intending to reclaim Giovanni as his own protégé by killing Beatrice? The story also refuses to indicate whether Giovanni ends up training 
with Rappaccini, Baglioni, or neither of them. Is Giovanni in the end only a conduit for Baglioni to destroy his enemy's main experimental evidence, Rappaccini's daughter, thereby discrediting him? By raising but not resolving these questions, Hawthorne brings to the fore larger questions about ideological conflict and false consciousness, particularly the idea that people in positions of authority in hegemonic institutions mislead those who consume their discourses. Both Giovanni and the reader are misled by the two doctors, and not only is Beatrice harmed, she is also harmful to others as the vehicle of poisons supposed to guarantee her invulnerability to disease. Her death therefore becomes an inversion of Mather's life-saving inoculation, which his contemporaries feared as simply a deliberate introduction of disease: she perishes before she can spread her medicinal poison. Yet across the two stories-and in spite of the increased personal stakes for the author and his new wife in doctors' competing claims-Hawthorne consistently points out the deadliness of medical factions protecting their own reputations at the cost of human lives.

By allegorizing the mechanisms of cultural consensus-making that, a century later, Gramsci would develop with the idea of hegemony, Hawthorne anticipated the increasingly complex battles for authority in twentieth- and twenty-first-century medicine. Following Hawthorne's career, allopathic medicine became the dominant system, endorsed by capitalism and government throughout the post-Flexner era. ${ }^{7}$ As Hawthorne underscores in these tales set in eras already distant to his own generation, history shines a light on the insidious manoeuvres among competitors in the present. His narrative politics provide a lens through which later theorists would identify the invisible working of hegemony over individual "choice" and decision-making.

This method of understanding conflict sheds light on current forces shaping medical care: politics, capitalism, and law. Medicine and the booming pharmaceutical industry repackage each others' claims in creating new diagnoses such as hyperactivity disorders (Kean 131) while a new class of psychotropic drugs has generated an increase in diagnosis of affective disorders (see, for example, Charles Barber's Comfortably Numb). Medical research seeks to maximize profit via patent law for ovarian and breast cancer gene-screening (Mears) and through deregulated vaccine testing in developing nations (Awad) - in both instances, girls and women are threatened with either blocked access to life-saving medical knowledge or exposure to lethal toxicity. ${ }^{8}$ Additionally, the ethics of genetic selection are debated fervently (Reynolds 268). Hawthorne's questions remain as urgent as ever: Whose interests have been at stake in the past, and whose interests are being served in the present? Who is responsible for just diagnosis and treatment? Who deserves healthcare? Who should pay for it?' As the U.S. Congress implements the Affordable Care Act, we might prepare for the future of healthcare by studying the ideological battles of our past. 


\section{NOTES}

1/ Dorothy Z. Baker illustrates Hawthorne's extensive use of Mather's writings on the debates of colonial Boston to reimagine New England history from a nineteenth-century viewpoint (America's Gothic Fiction: The Legacy of Magnalia Christi Americana. Columbus: Ohio State UP, 2007. Print).

2/ Compare "The Rejected Blessing” (98) and Diary of Cotton Mather, Volume II (620-21).

3/ It is worth noting that Hawthorne's Beatrice in "Rappaccini's Daughter" was quite possibly inspired by Dante Alighieri's muse, Beatrice Portinari, daughter of the founder of Florence's first public hospital, who died at age twenty-four. The Divine Comedy and The Inferno are established sources for "Rappaccini's Daughter” (see William Sayers's “Gardens of Horror and Delight: Hawthorne's 'Rappaccini's Daughter' and Boccaccio's Decameron" [Nathaniel Hawthorne Review 32.1 (2006): 30, 35. Print]).

4/ A few studies of "Rappaccini's Daughter" have delineated Hawthorne's knowledge of and attitudes toward science. For the Renaissance context, see Carol Marie Bensick's La Nouvelle Beatrice: Renaissance and Romance in "Rappaccini's Daughter" (New Brunswick: Rutgers UP, 1985. Print). Studies addressing Hawthorne and medicine in the eighteen-forties include James N. Mancall's "Thoughts Painfully Intense" and M.D. Uroff's “The Doctors in 'Rappaccini's Daughter” (Nineteenth-Century Fiction 27.1 [1972]: 61-70. Print). None has examined the sociopolitical implications of Hawthorne's attitudes toward institutional conflict.

5/ Gramsci's ideas on hegemony tend to be presented more clearly and concisely in Pre-Prison Writings (240-43, 322) than in Selections from the Prison Notebooks and Selections from Cultural Writings (Ed. David Forgacs and Geoffrey Nowell-Smith. Trans. William Boelhower. Cambridge: Harvard UP, 1991. Print). See also Richard Bellamy's introduction to Pre-Prison Writings (xxvii) and Pollock (514-15; 520-21).

6/ See Margaret Hallissy's Venomous Woman: Fear of the Female in Literature (New York: Greenwood, 1987. 125-33. Print) and Luther S. Luedtke's Nathaniel Hawthorne and the Romance of the Orient (Bloomington: Indiana UP, 1989. 77-79. Print).

7/ See Chapter 3 of Paul Starr's The Social Transformation of American Medicine (New York: Basic, 1982. Print).

8/ For more on Zeina Awad's coverage of Gardasil trials for the Human Papilloma Virus in Indian girls and an overview of the drug development market in developing nations, see Kaushik Sunder Rajan's Biocapital: The Constitution of Postgenomic Life (Chapel Hill: Duke UP, 2006. Print).

9/ In Remedy and Reaction: The Peculiar American Struggle Over Health Care Reform, Paul Starr details the history of U.S. health insurance that updates Hawthorne's focus on competing medical systems with a contest between twentieth-century market capitalism and electoral politics, a contest that repeatedly leaves questions about the healthcare needs of individual citizens almost entirely out of the battle (New Haven: Yale UP, 2013. Print).

\section{WORKS CITED}

Awad, Zeina. “Outsourced: Clinical Trials Overseas.” Al Jazeera. Al Jazeera English. 11 Jul. 2011: n. pag. Web. 5 Jun. 2013.

Barber, Charles. Comfortably Numb: How Psychiatry Is Medicating a Nation. New York: Vintage, 2009. Print.

Boylston, Zabdiel. Some Account of What is Said of Inoculation or Transplanting the Small Pox by the Learned Dr. Emanuel Timonius and Jacobus Pylarinus. Boston, 1721. Print.

Browner, Stephanie P. Profound Science and Elegant Literature: Imagining Doctors in Nineteenth-Century America. Philadelphia: U of Pennsylvania P, 2005. Print.

Gramsci, Antonio. Pre-Prison Writings. Ed. Richard Bellamy. Trans. Virginia Cox. Cambridge: Cambridge UP, 1994. Print. 
. Selections from the Prison Notebooks of Antonio Gramsci. New York: International Publishers, 1971. Print.

Haller, John S. American Medicine in Transition, 1840-1910. Urbana: U of Illinois P, 1981. Print.

Hawthorne, Nathaniel. "The Celestial Rail-Road.” Nathaniel Hawthorne: Tales and Sketches. New York: Literary Classics, 1982. 808-24. Print.

. "Earth's Holocaust." Nathaniel Hawthorne: Tales and Sketches. New York: Literary Classics, 1982. 887-906. Print.

. "The New Adam and Eve." Nathaniel Hawthorne: Tales and Sketches. New York: Literary Classics, 1982. 746-63. Print.

. "Rappaccini's Daughter." Nathaniel Hawthorne: Tales and Sketches. New York: Literary Classics, 1982. 975-1005. Print.

. "The Rejected Blessing." The Whole History of Grandfather's Chair: A History for Youth. New York: James B. Millar, 1884. 96-113. Print.

Kean, Brian. “The Risk Society and Attention Deficit Hyperactivity Disorder (ADHD): A Critical Social Research Analysis Concerning the Development and Social Impact of the ADHD Diagnosis." Ethical Human Psychology and Psychiatry 7.2 (2005): 131-42.

Mancall, James N. "Thoughts Painfully Intense": Hawthorne and the Invalid Author. New York: Routledge, 2002. Print.

Mather, Cotton. Diary of Cotton Mather, Volumes I \& II. New York: Frederick Ungar, 1957. Print. . Magnalia Christi Americana, Books I and II. Ed. Kenneth B. Murdock. Cambridge: Belknap P of Harvard UP, 1977. Print. . Selected Letters of Cotton Mather. Ed. Kenneth Silverman. Baton Rouge: Louisiana State UP, 1971. Print.

Mears, Bill. "Justices at Odds Over Patents for Human Genes." CNN Health. Cable News Network. 17 Apr. 2013: n. pag. Web. 3 Jun. 2013.

Mellow, James R. Nathaniel Hawthorne in His Times. Baltimore: Johns Hopkins UP, 1980. Print.

Pollock, Sheldon. The Language of the Gods in the World of Men: Sanskrit, Culture, and Power in Premodern India. Berkeley: U of California P, 2006. Print.

Reynolds, M.T. “Down Syndrome Screening is Unethical.” Journal of Clinical Pathology 56.4 (2003): 268-70. Print.

Ricoeur, Paul. From Text to Action: Essays in Hermeneutics, II. Trans. Kathleen Blamey and John B. Thompson. Evanston: Northwestern UP, 1991. Print.

. Lectures on Ideology and Utopia. Ed. George Taylor. New York: Columbia UP, 1986. Print.

Silverman, Kenneth. The Life and Times of Cotton Mather. New York: Harper and Row, 1984. Print.

Totaro, Rebecca. “English Plague and New World Promise.” Utopian Studies 10.1 (1999): 1-12. Print.

van de Wetering, Maxine. “A Reconsideration of the Inoculation Controversy.” New England Quarterly 58.1

(1985): 46-67. Print.

Wineapple, Brenda. Hawthorne: A Life. New York: Alfred A. Knopf, 2003. Print. 
ANTHONY CERULLI is Assistant Professor of Religious Studies and Asian Studies at Hobart and William Smith Colleges. He is the author of Somatic Lessons: Narrating Patienthood and Illness in Indian Medical Literature and co-editor of Medical Texts and Manuscripts in Indian Cultural History.

SARAH BERRY is Visiting Assistant Professor of English at Hobart and William Smith Colleges. She is the author of articles on narrative, medicine, gender, and race, including "'No doctor but my master': Health Reform and Antislavery Rhetoric in Harriet Jacobs's Incidents in the Life of a Slave Girl." 